Arab Univ. J. Agric. Sci., Ain Shams Univ., Cairo, 14(2), 643-660, 2006

\title{
EFFECT OF PASTEURIZATION AND STORGE ON FLAVOUR OF APPLE AND KIWIFRUIT BLEND JUICE
}

[41]

\author{
Magda A. Abd El-Mageed ${ }^{1}$ and Emad El-Din Ragheb ${ }^{2}$
}

\begin{abstract}
A blend Juice prepared from apple juice and kiwifruit juice (60:40 v/v), was pasteurized and stored for 3 and 6 months at $4^{\circ}$ and $25^{\circ} \mathrm{C}$ untill analysis. Sensory evaluation showed significant differences between the fresh and pasteurized blend juice in all sensory attributes. The headspace volatiles of fresh apple, fresh kiwifruit, fresh and stored pasteurized blend juice at different temperatures were collected and subjected to GC and GC-MS analysis. A total of 33 volatile components were identified, 18 esters (17 aliphatic and one aromatic), 6 alcohols, 3 aldehydes, 3 terpenic hydrocarbons, 2 ketones and 1 carboxylic acid. The volatile components in the pasteurized blend juice showed considerable quantitative and qualitative variations during storage. By comparative study between the blend juice and fresh apple, fresh kiwifruit juices it was clear that the pasteurization process caused a remarkable increase in the total esters content due to the high increase in methyl propanoate, methyl butanoate and methyl benzoate. Pasteurization caused a sharp decrease in butanol which is the most abundant compound in fresh apple juice. All alcohols showed the same trend except ethanol. Pasteurization revealed a remarkable decrease in $(E)-$ 2-hexenal which is the most abundant compound in fresh kiwifruit juice. Regarding the effect of storage it was noted that the blend juice stored at $4^{\circ} \mathrm{C}$ showed high quality after 3 months due to the remarkable increase in the contents of total ester, butanol, and $(E)-2$ - hexenal with a decrease in limonene, but after 6 months the good quality was attributed to the high increase in ethyl butanoate concentration. While stroage at $25^{\circ} \mathrm{C}$ showed good quality after 3 months due to the very high increase in total esters content which attributed to a greate increase in ethyl butanoate concentration (which gave sweet and fruity aroma to juice), but storage for 6 months gave rise to a sharp decrease in ethyl butanoate which led to a high loss in aroma quality.
\end{abstract}

Keywords: Apple juice, Kiwifruit juice, Pasteurization, Storage, Flavour

1- Chemistry of Flavour and Aroma Department, National Research Centre, Cairo, Egypt

2- Food Science and Technology Research Institute, Giza, Egypt

(Received May 15, 2006)

(Accepted June 14, 2006) 


\section{INTRODUCTION}

Consumers in advanced nations desire to have a juice that has the flavour of freshly squeezed products. In the manufacture of fruit juices, evaporation in the juice concentration process and thermal treatment in the pasteurizing process are critical factors that may contribute to flavour deterioration (Schreier, 1981; Sheu and Wiley, 1983; Yu and chiang, 1986; Drake and Nelson, 1987; Lue and Chiang, 1989; Myrna, et al 1990; Cliff, et al 2000). Researchers have reported that apple juices and concentrates contained less than half the volatile components present in the original fruit (Peredi, et al 1981). Rao, et al (1987) reported that eight odour-active volatiles of apple juice were partially lost after being processed with a plate and frame filtration (PFF), vacuum drum (VDR) or ultrafiltration (UF) system. Chou, et al (1991) reported losses of $55.3-75.4 \%$ hexanal and $33.3-57.9 \%$ ethyl 2-methyl butyrate in apple juice concentrate processed by reverse osmosis (RO).

Fruit juices are commonly treated at 90-100 ${ }^{\circ} \mathrm{C}$ to increase their shelf life. The quality optimization by thermal processing is possible due to the difference in temperature dependencies of the inactivation of target microorganisms and the thermal degradation of sensory attributes (Lund, 1977).

Su and Wiley (1998) determined the flavour compound losses or changes due to enzyme, microfiltration and pasteurization of apple juice during commercial processing. Cliff, et al (2000) carried out the sensory evaluation of flavour and aroma attributes for experimental apple juices produced by micro-filtration and a commercial pasteurized juice. Shimoda, et al (2003), investigated the influences of thermal processing on the odour attributes of reconstituted apple juice.

The flavour of kiwifruit [Actinidia deliciosa var. deliciosa cv. Hayward] appears to be a subtle blend of several volatile components. The fruit softens considerably during ripening, which produces a large number of volatile compounds (Young and Paterson, 1995). The composition of this volatile fraction has been the subject for several studies (Young and Paterson 1985; Takeoka, et al 1986; Takeoka 1987; Paterson, et al 1991, Gilbert, et al 1996; Pino 1997; Jung and Young 1997; Wan, et al 1999; Jordan, et al 2002 and Matich, et al 2003). About 80 volatile components have been reported in these studies among them, the main identified components were methyl and ethyl butanoate, hexanal, (Z)- and (E)-2-hexenal, hexanol, $(Z)$-, and $(E)-3$-hexenol, and methyl benzoate.

A sensory and instrumental analysis of the aroma of kiwifruit by Pfannhauser (1988) yielded a total of 52 compounds. His results showed a rapid change in the volatile composition from fresh/ mature to the overripe or frozen state with a decrease in C6 compounds such as hexanal, hexenol, and ethyl butyrate and an increase in terpene esters. These changes occur in parallel to changes in the sensory impression of kiwi aroma from a fresh/ green to an undesired ester note.

Early Young, et al (1983) olfactometrically evaluated the kiwifruit volatiles and reported $(E)$-2-hexenal and the butanoate esters, with some contributions from the C6 alcohols, as the most aroma active components. Studies by Bartley and Schwede (1989) identified 27 components in kiwifruit and declared that 2- 
hexenal was the major component in mature fruit but on further ripening ethyl butanoate began to dominate the profile. These results were confirmed years later by Jung and Young (1997), who studied the effect of storage period on the flavour components of Korean kiwifruit.

Young and Patterson (1995) studied the characterization of bound flavour components in kiwifruit and detected the volatile components that were released by enzymatic hydrolysis with B-glucosidase. Major compounds found and identified were $(E)$-2-hexenal and benzaldehyde. The compounds that not previously identified included octan-3-ol, camphor, 4-methylbenzaldehyde, 2hydroxybenzaldehyde, neral, geranial, methyl 2-hydroxybenzoate, nerol, geraniol, and 2-phenylethanol. Pino (1997) defined a total of 48 volatile components of which ethyl benzoate, hexanal, and (E)-2-hexenal were the major contributors to the aroma of kiwi juice. More recently Wan, et al (1999) identified 42 volatile components in kiwifruit by SPME-GC-MS, with 4-pentenal, $(E, E)$ 2,4-nonadienal, 2-nonanone, ethyl octanoate, butyrolactone, and 2-propenyl butanoate were reported for the first time in this fruit.

The aim of this study is to determine the effect of pasteurization and storage on the flavour changes of apple and kiwifruit blend juice, stored at two different temperatures $4^{\circ}$ and $25^{\circ} \mathrm{C}$ for 3 and 6 months.

\section{MATERIAL AND METHODS}

The freshly picked large mature apples (var.Anna) were obtained from an orchard at Cairo-Alexandria desert road. The fresh mature kiwifruit (Actinidia deliciosa) were purchased from local mar- ket. The authentic compounds were purchased from Sigma and Aldrich Co.,s.

\section{Preparation of apple and kiwifruit blend juice}

Apple fruits were washed, cut into halves, the juice was extracted then clarified with cloth to separate fibers and seeds. 250 gms sugar were added to every litre of juice and the sugar was dissolved. The juice of kiwifruit was extracted clarified and sugar was added as mentioned above. A blend juice was prepared containing $60 \%$ apple juice and $40 \%$ kiwi juice (v/v), citric acid and pectinase enzyme were added followed by filteration on asbestos with cotton. Clarification was performed by heating the blend juice at $85^{\circ} \mathrm{C}$ for $1 \mathrm{~min}$, then filtered through a cloth, and pasteurized at $95^{\circ} \mathrm{C}$ for $25 \mathrm{mi}$ nutes then immidiately cooled and packaged in $120 \mathrm{ml}$ glass bottles which were sterilized at $100^{\circ} \mathrm{C}$ for 5 minutes then stored at two temperatures $4^{\circ} \mathrm{C}$ (refrigerator) and $25^{\circ} \mathrm{C}$ (room temperature) untill analysis.

\section{Sensory evaluation}

The organoleptic properties of the fresh unpasteurized blend juice (control sample) and pasteurized blend juice were evaluated by 10 experienced assessors. The panelists were asked to evaluate the samples according to their quality characteristics (colour, flavour, taste, consistency and overall acceptability) on 1-10 hedonic scale, where 1 was dislike extremely and 10 was like extremely (Larmond, 1967), in comparison with the fresh blend juice which was given the highest scores (10) for all sensory attributes. The mean scores were compared for statistical dif- 
ferences using Tukey's test (Steel and Torrie, 1980).

\section{Isolation of headspace volatiles}

The volatiles in the headspace of each sample under investigation were isolated by using a dynamic headspace system. The samples were purged for $1 \mathrm{~h}$ with nitrogen gas (grade of $\mathrm{N} 2>99.99$ ) at a flow rate $100 \mathrm{ml} / \mathrm{min}$. The headspace volatiles were swept into cold traps containing diethyl ether and pentane (1:1, $\mathrm{v} / \mathrm{v}$ ) and held at $-10^{\circ} \mathrm{C}$. The solvents containing the volatiles were dried over anhydrous sodium sulfate for $1 \mathrm{~h}$. The volatiles were obtained by evaporation of the solvents under reduced pressure (Fadel, et al 2000).

\section{Gas chromatographic (GC) analysis}

GC analysis was performed by using Hewlett-Packard model 5890 equipped with a flame ionization detector (FID). A fused silica capillary column DB5 (60m x $0.32 \mathrm{~mm}$ id) was used. The oven temperature was maintained initially at $50^{\circ} \mathrm{C}$ for 5 min, then programmed from 50 to $250^{\circ} \mathrm{C}$ at a rate of $4^{\circ} \mathrm{C} / \mathrm{min}$. Helium was used as the carrier gas, at flow rate $1: 1 \mathrm{ml} / \mathrm{min}$. The injector and detector temperatures were 220 and $250^{\circ} \mathrm{C}$, respectively. The retention indices (Kovats index) of the separated volatile components were calculated using hydrocarbon (C8-C22, Aldrich CO.) as references.

\section{Gas chromatographic-mass spectrome- tric (GC-MS) analysis}

The analysis was carried out by using a coupled gas chromatography HewlettPackard (5890)/mass spectrometry Hew-
lett-Packard-MS (5970). The ionization voltage was $70 \mathrm{eV}$, mass range $\mathrm{m} / \mathrm{z} 39$ 400amu. The GC condition was carried out as mentioned above. The isolated peaks were identified by matching with data from the library of mass spectra (NIST) and compared with those of authentic compounds and published data (Adams, 1995). The quantitative determination was carried out based on peak area integration.

\section{RESULTS AND DISCUSSION}

\section{1- Effect of pasteurization on the orga- noleptic characteristics of apple and kiwifruit blend juice}

As shown in Table (1) there are remarkable differecnces between the pasteurized and fresh juices concerning the colour, odour, taste, consistency and overall acceptability. These results are consistent with Moshonas and Shaw 1997 who reported that sensory panels detected flavour differences between the unheated juice and the heavily heated juice. Yulianti, et al 2004 reported that the acceptability of pasteurized apple cider could be related to significant differences in the content of several esters that are important contributors to apple flavour.

\section{2- Volatile components in headspace of fresh apple juice, fresh kiwifruit juice and their pasteurized blend juice stored for 3 and 6 months at two temperatures $\left(4^{\circ}\right.$ and $\left.25^{\circ} \mathrm{C}\right)$}

The separated volatile components as identified by comparison of their mass spectra with library (NIST) and with those of authentic compounds and published data are cited together with their area percentages in Table (2). 
Table 1. Effect of pasteurization on the organoleptic characteristics of apple and kiwifruit blend juice

\begin{tabular}{|lccccc|}
\hline & $\begin{array}{c}\text { Colour } \\
\text { Mean } \pm \text { SD }\end{array}$ & $\begin{array}{c}\text { Odour } \\
\text { Mean } \pm \\
\text { SD }\end{array}$ & $\begin{array}{c}\text { Taste } \\
\text { Mean } \pm \text { SD }\end{array}$ & $\begin{array}{c}\text { Consistency } \\
\text { Mean } \pm \text { SD }\end{array}$ & $\begin{array}{c}\text { Overall } \\
\text { acceptability } \\
\text { Mean } \pm \text { SD }\end{array}$ \\
\hline Fresh blend juice (control) & 10 & 10 & 10 & 10 & 10 \\
Pasteurized blend juice & $8.5 \pm 0.82$ & $7.5 \pm 0.92$ & $7.2 \pm 0.99$ & $7.3 \pm 1.05$ & $8.2 \pm 0.60$ \\
\hline
\end{tabular}

SD: Standard deviation

Values are the mean of 10 assessors \pm SD.

The typical gas chromatograms of the volatiles of fresh juices, pasteurized blend juice before and after storage for 3 and 6 months at 4 and $25^{\circ} \mathrm{C}$ are shown in Fig.s (1-3).

The total area percentages of the main chemical classes of volatile components in the headspace of all investigated samples are shown in Fig. (4).

Thirty three volatile components were identified and reported in Table (2), they included 18 esters, 6 alcohols, 3 aldehydes, 3 terpenic hydrocarbons, 2 ketones and 1 carboxylic acid. The eraly studies cleary showed that the characteristic apple aroma/flavour results from a complex mixture of alcohols, esters, aldehydes and ketones (Young, et al 1996).

The aroma compounds determined by headspace gas-chromatographic analysis of fresh apple juice under investigation were esters $(33.84 \%)$, alcohols $(59.07 \%)$, aldehydes $(2.58 \%)$, hydrocarbons $(2.33 \%)$ and ketones (1.99\%), Fig. (4). This distribution agrees with the results found by Poll, et al (1996) who found that the headspace volatiles of apple juice were consisting of $20 \%$ esters, $73 \%$ alcohols and 6\% C-6 aldehydes.
As shown from Table (2) 16 ester compounds were identified in the volatiles of fresh apple juice, among them ethyl butanoate $(14.49 \%)$, hexyl acetate $(3.5 \%)$, ethyl hexanoate $(2.25 \%)$, ethyl propanoate $(2.15 \%)$, methyl butanoate $(2.09 \%)$, 2-methyl butyl acetate $(1.22 \%)$ and methyl benzoate $(2.63 \%)$ were the major esters. Previous studies (Kakiuchi, et al 1986; Brockhoff, et al 1993) have shown that the esters are important for the sensory impression because of their type of smell and their low odour thresholds.

2-Methyl butyl acetate and hexyl acetate are present in considerable concentrations in the headspac volatiles of fresh apple juice $(1.22 \%$ and $3.50 \%$, respectively) Table (2). These 2 components with butanol which is the predominant alcohol and the major compound in volatiles of fresh apple juice under investigation $(31.31 \%)$ are responsible for apple flavour. Young, et al (1996) found that red apple aroma and red apple flavour increased with increasing levels of 2methyl butyl acetate, butanol and hexyl acetate. These results are in agreement with those obtained by Fadel, et al (2000) who reported that butyl acetat and 
Arab Univ. J. Agric. Sci., 14(2), 2006 


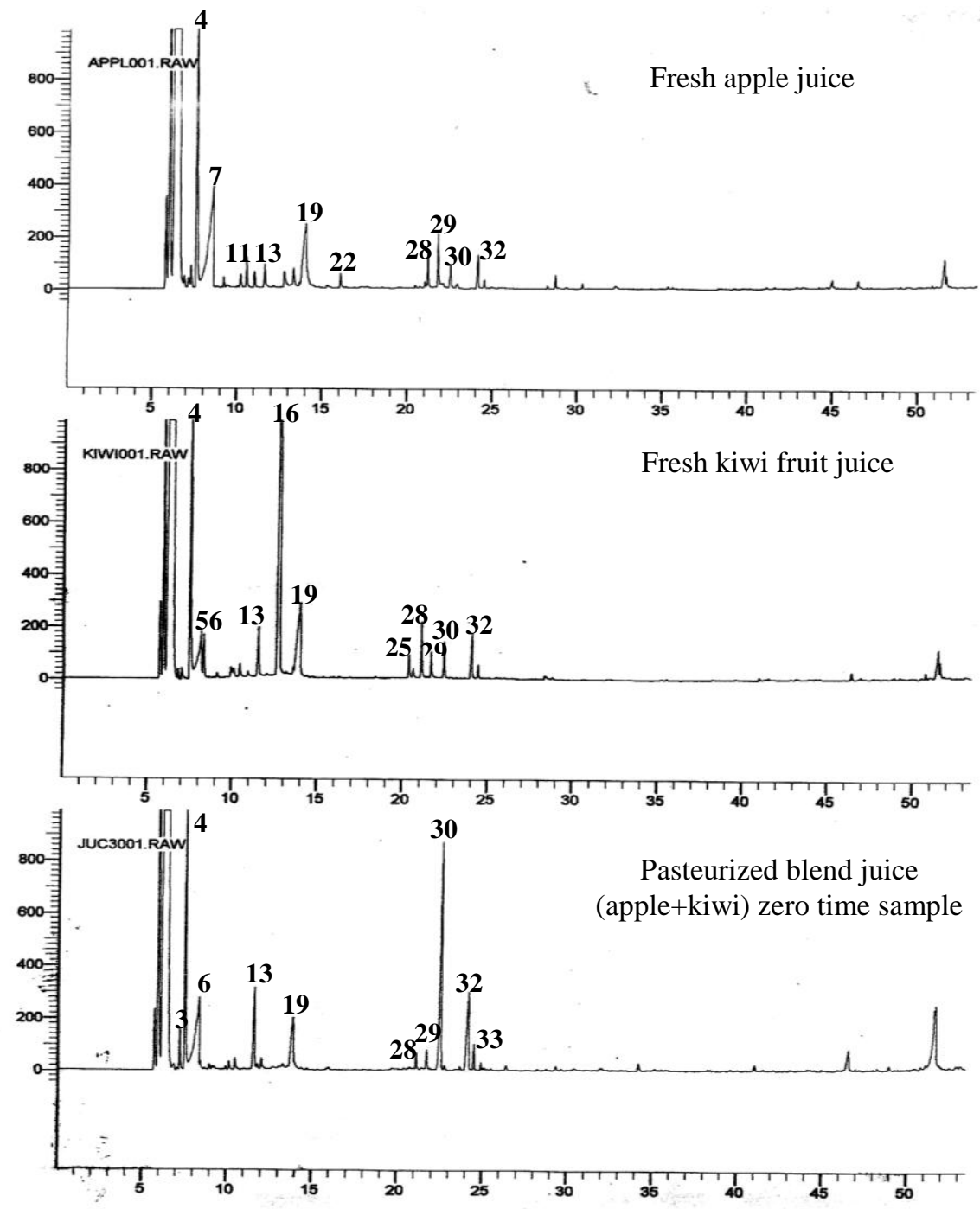

Fig 1. Gas chromatograph of volatiles in headspace of fresh apple juice, fresh kiwifruit juice and their pasteurized blend juice 


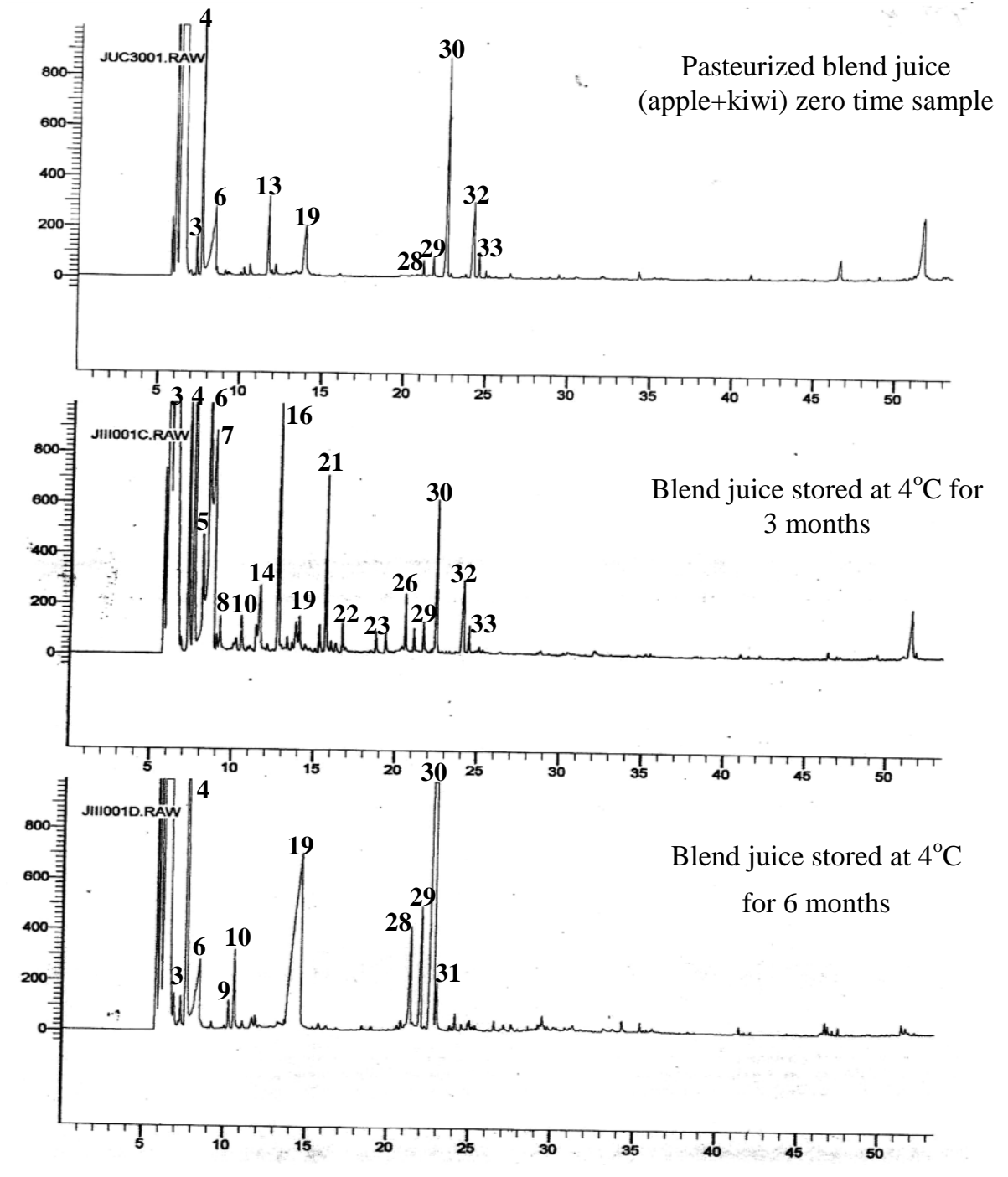

Fig. 2. Gas chromatograph of volatiles in headspace of Pasteurized blend juice zero time sample and stored samples at $4^{\circ} \mathrm{C}$ for 3 and 6 months 


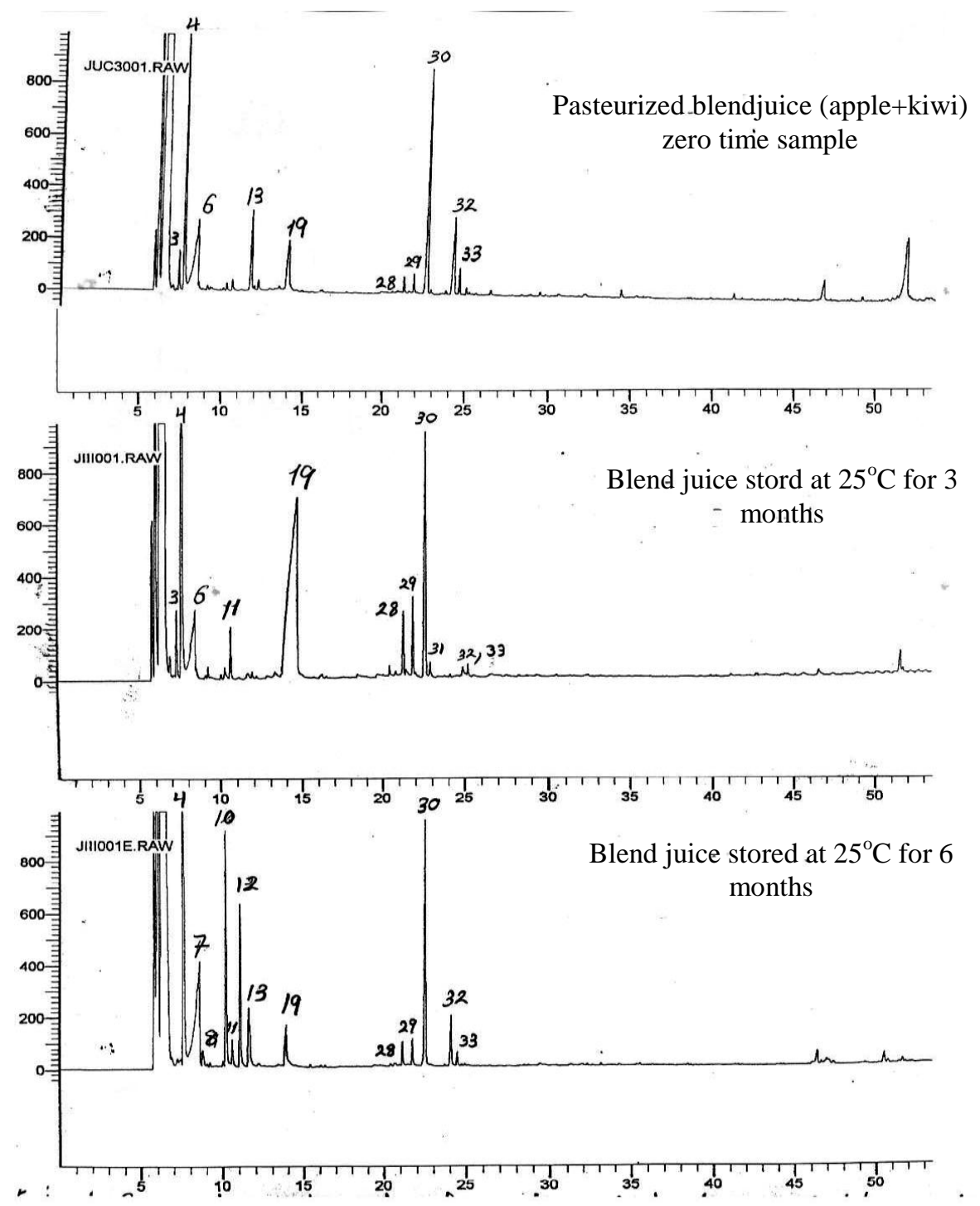

Fig. 3. Gas chromatograph of volatiles in headspace of Pasteurized blend juice zero time sample and stored samples at $25^{\circ} \mathrm{C}$ for 3 and 6 months 


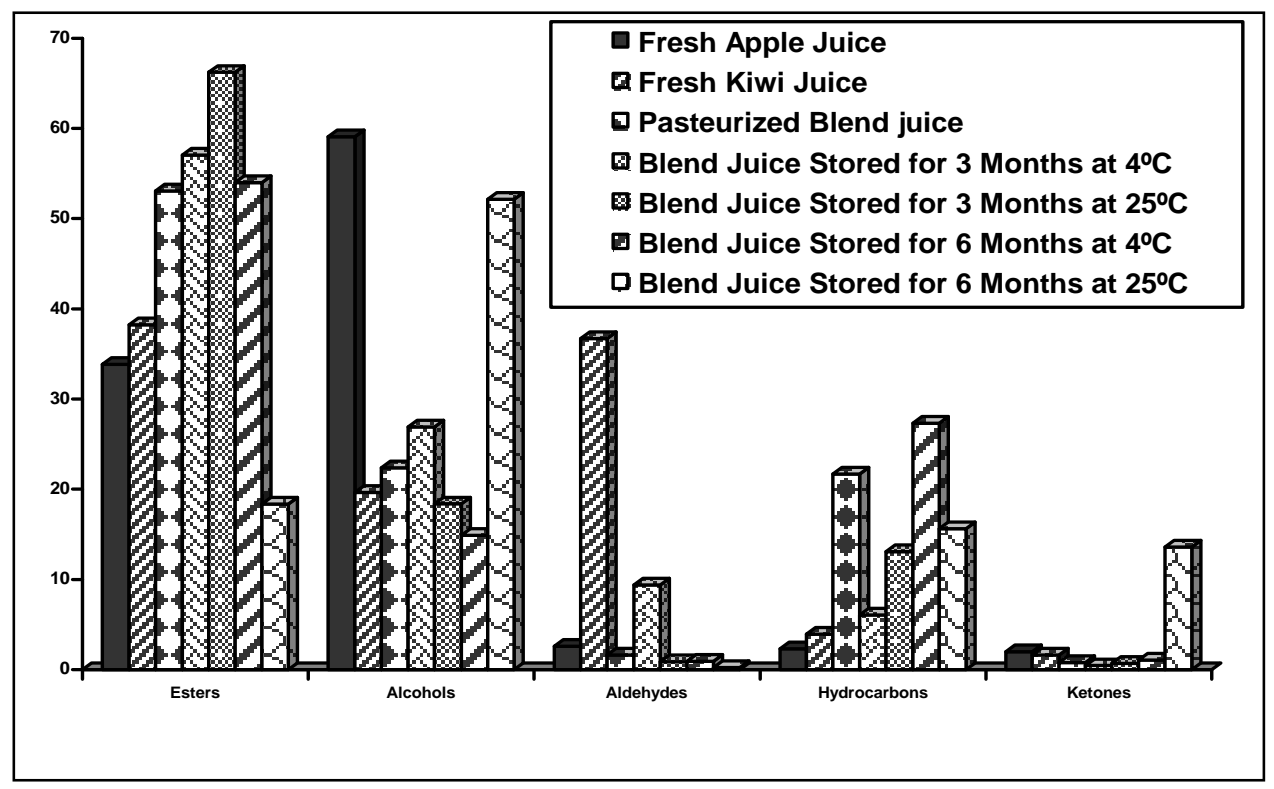

Fig. 4. The total area percentages of the main chemical classes of volatile components in the headspace of fresh apple juice, fresh kiwifruit juice, Pasteurized blend juice kiwifruit zero time and stored for 3 and 6 months at $4^{\circ}$ and $25^{\circ} \mathrm{C}$

hexyl acetate accounting more than $60 \%$ of the total volatiles of fresh Anna apple.

Eleven esters compounds were detected and dominated in volatiles of fresh kiwifruit juice Table (2). Their total concentration was $38.22 \%$, Fig. (4). The most abundant constituents were ethyl butanoate $(13.27 \%)$ ethyl acetate $(8.51 \%)$, methyl butanoate $(3.72 \%)$, ethyl hexanoate $(3.14 \%)$, methyl propanoate $(2.47 \%)$, hexylacetate $(1.43 \%)$ and methyl benzoate $(3.28 \%)$, Table (2). These results confirm those previously reported by Young, et al (1983); Winterhalter (1991) and Paterson, et al (1991); Gilbert, et al (1996); Jordan, et al (2002) and Matich, et al (2003).
The total esters content of pasteurized blend juice was $53.07 \%$ of the total content of aroma compounds, Fig. (4). This notable increase, compared with those in fresh apple and fresh kiwifruit juces, may be attributed to the high increase in methyl propanoate, methyl butanoate and methyl benzoate $(18.63 \%, 7.42 \%$ and 9.7\%, respectively) Table (2) as a result of pasteurization process. (Su and Wiley, 1998; Dixon and Hewett 2001; Yulianti, et al 2004).

On the other hand as shown in Fig. (4) the content of esters showed considerable increase in blend juice after storage for 3 and 6 months at $4^{\circ} \mathrm{C}(57.05 \%$ and $54.02 \%$, respectively), this increase may be attributed to the remarkable increase in 
methyl propanoate $(19.15 \%)$, ethyl ethanoate $(9.12 \%)$, ethyl-2- methyl butanoate $(4.83 \%)$, isobutyl acetate $(2.88 \%)$ and propyl acetate $(1.75 \%)$, after 3 months, but after 6 months the increase in esters concentration was attributed to the increase in ethyl butanoate from $3.28 \%$ to $33.24 \%$, Table (2). These results agree with those of Young, and Paterson (1985) and Wan, et al (1999).

The esters content in the blend juice stored at $25^{\circ} \mathrm{C}$ for 3 months showed the same trend however it showed considerable decrease at the end of storage period to be $18.37 \%$ Fig. (4), this may be a result of increasing in ethyl butanoate concentration $(46.51 \%)$ after the first 3 months which followed by a sharp decrease to be (3.24\%) at the end of storage, Table (2). The same behaviour were found in our previous study on the effect of storage on pasteurized blend juice of orange and cantaloupe (Abd El Mageed and Ragheb 2005). Matich, et al (2003) Found that ethyl butanoate dominated headspace extracts with concentration ranged between 2 to $66 \%$ in several kiwifruit genotype. Also it was the only ester judged to contribute to kiwifruit flavour (Young and Paterson 1995). Lavilla, et al (1999) found that after different coldstorage periods, a total of 15 volatile compounds were detected in Granny Smith apples, 11 of them were esters, which constitute $>84 \%$ of the total aroma compounds emitted after 3 and 5 months.

Also Fallik, et al (1997) found that the total volatile esters from heat - treated fruit declined after 1 week of storge but had increased 4- folds from the initial sampling date after 6 weeks of storage. Wan, et al (1999) determined the evolution of the main flavour components of ripe kiwifruit after storage for various time periods. Su and Wiley (1998) reported that, the high temperatures used $\left(\sim 85^{\circ} \mathrm{C}\right)$ for pasteurization decreased all flavour compounds except propyl butyrate which increased.

Six alcohols were identified in the headspace volatiles of fresh apple juice and considered the predominant compounds which comprised $59.07 \%$ of the total flavour components, Fig. (4). Ethanol and butanol are the major alcohols of fresh apple juice $(23.94 \%, 31.31 \%$ respectively) Table (2). This result confirm that reported by Dixon and Hewett (2001) who found that ethanol and butanol were the major alcohols in Fuji and Royal Gala apples and their concentrations increased as temperature increased. Also they were the two major alcohols in apple juice model solution (Bengtsson, $\boldsymbol{e t}$ al 1989). Butanol is the most abundant component in fresh Anna apple juice, Table (2). Young, et al (1996) reported that butanol is one of the most abundant components of the flavour volatiles in Royal Gala apple and overall apple aroma and overall flavour increased with increasing levels of 2-methyl butylacetate and butanol. The total concentration of alcohols in volatiles of fresh kiwi juice were $19.67 \%$, ethanol comprised $18.21 \%$, from this ratio, Table (2). This result is in agreement with Paterson, et al (1991) who found that ethanol was the most abundant volatile in mature kiwifruit. Also ethanol was the major alcohol in pasteurized blend $(21.49 \%)$ juice and in the all stored samples $(12.7 \%, 17.1 \%, 14.42 \%$ and $22.62 \%$, respectively) Table (2). Pasteurization process caused a decrease in all alcohols except for ethanol besides 3methyl butanol and hexanol were not detected. Storage of blend juice at $4^{\circ} \mathrm{C}$ for 3 months led to a sharp decrease in etha- 
nol concentration and a high increase in butanol concentration to reach $12.42 \%$ Table (2), this gave rise to an increase in the total content of alcohols (26.93\%) followed by a sharp decrease at the end of storge $(14.89 \%)$ due to disappearance of butanol, Fig. (4). On the contrary the effect of storage on pasteurized blend juice at $25^{\circ} \mathrm{C}$ showed a total concentration of alcohols $18.38 \%$ after 3 months, followed by a large increase to reach approximatly three folds of this ratio to be $52.17 \%$ at the end of storage, Fig. (4). This remarkable increase is attributed to the great increase in ethanol, butanol and 3-methyl butanol concentrations to reach $(22.62 \%$, $20.73 \%$ and $8.26 \%$, respectively) at the end of storage period Table (2). These results are in accordance with Lavilla, $\boldsymbol{e t}$ al (1999) who found that in Granny Smilh apples during 1,5,10 days of shelf life $\left(20^{\circ} \mathrm{C}\right)$ after 3,5 months of cold storage under different controlled- atmosphere, the ester production was significantly higher in apples stored in the standard controlled- atmosphere and lowoxygen also produced an increase in all alcohols except for 1-propanol till after 7 monthes showed significantly higher concentration of 1-butanol. Also Wan, et al (1999) confirmed of this result, they found an increase in ethanol in kiwifruit flavour afte 5 months of storage. Ethanol is produced by reduction of acetaldehyde by alcohol dehydrogenase (ADH) (Bartley and Hindley 1980).

Acetaldehyde, hexanal and 2-hexenal are the three aldehydes identified in headspace volatiles of fresh apple and fresh kiwifruit juices, Table (2). (E)-2-hexenal is the most abundant compound in volatiles of fresh kiwifruit juice $(36.07 \%)$ Table (2). (E) -2-Hexenal and hexanal are important contributors to kiwifruit flavour. (Jordan, et al 2002). Matich, et al (2003) found that (E)-2- hexenal was $1-58 \%$ in headspace extracts in kiwifruit (Actinidia arguta).

Although the total concentration of aldehydes was $2.58 \%$ in fresh apple juice and $36.73 \%$ in fresh kiwifruit juice, it showed a sharp decrease in pasteurized blend juice to become $1.63 \%$, Fig. (4).

Storage caused an increase in the total aldehydes content to reach $9.37 \%$ after three months of storage at $4^{\circ} \mathrm{C}$ followed by a sharp decrease in each of the other treated stored sample $\left(4^{\circ} \mathrm{C}\right.$ for 6 months and $25^{\circ} \mathrm{C}$ for 3 and 6 months) Fig. (4). Hexanal and (E)-2- hexenal have tallowy /leaf-like, apple like/ leafy/ green/ fatty/ unripe-fruit (concentration dependent) notes respectively (Rychlik, et al 1998). These compounds are products of lipoxygenase breakdown of long-chain fatty acids such as lenolenic acid (Matheis, 1995).

$\beta$-pinene, myrecene and D-limonene were the three terpenic hydrocarbons identified in headspace volatiles of fresh apples and fresh kiwifruit juices Table (2). (Fallik, et al 1997; Jordan, et al 2002 and Matich, et al 2003). Pasteurization process caused an increase in limonene concentration to reach $21.67 \%$ in the blend juice with disapearance of $\beta$ pinene and myrecene, Table (2). Also storage gave rise to an increase in total hydrocarbon contents for all stored samples at two temperatures $\left(4^{\circ}\right.$ and $\left.25^{\circ} \mathrm{C}\right)$ for 3 and 6 months recording $(6.08 \%$, $13.09 \%, 27.32 \%$, and $15.63 \%$, respectively) compared to their concentrations in fresh apple and fresh kiwifruit juices (2.33\% and $3.94 \%$ respectively), Fig. (4); this increase was attributed to the increase in limonene content which is the major hydrocarben in all samples (Abd 
El-Mageed and Ragheb 2005; Fallik, et al 1997).

Two ketones (2-propanone and 1penten-3-one) were represented in fresh apple juice by $1.99 \%$ and in fresh kiwifruit juice by $1.62 \%$, while their concentrations decreased in pasteurized blend juice and in all stored samples except for the sample stored at $25^{\circ} \mathrm{C}$ for 6 months which showed a remarkable increase in total ketones content to reach $13.58 \%$ as a result of the high increase in 1-penten-3one (13.17\%) Table (2) (Paterson, et al 1991).

From the above mentioned results it is obvious that storage of the pasteurized blend juice at $4^{\circ} \mathrm{C}$ gave rise to a high stability of the volatile components responsible for the sweet and fruity aroma.

\section{REFRENCES}

Abd El-Mageed, M.A. and E.E. Ragheb (2005). Flavour Changes of blends of pasteurized orange juice with either cantaloupe or grapefruit juices during storage. Egyptian J. of Nutrition 20(3): 3575.

Adams, R.P. (1995). Identification Essential Oil Components by Gas Chromatography / mass Spectrometry. Allured Publishing Carol Stream. Ilinois, USA.

Bartley, I.M. and S.J. Hindley (1980). Alcohol dehydrogenase of apple. J. Expt. Bot. 31: 449-459.

Bartley, J.P. and A.M. Schwede (1989). Production of volatile compounds in ripening kiwifruit (Actinidia chinensis). $J$. Agric. Food Chem., 37: 1023-1025.

Bengtsson, E.; G. Tragardh and B. Hallstrom (1989). Recovery and concentration of apple juice aroma compounds by pervaporation. J. Food Engineering 10: 65-71.

Brockhoff, P.; I. Skovgaard; L. Poll and K. Hansen (1993). A comparison of methods for linear prediction of apple flavour from gas chromatographic measurements. Food Qual. Pref. 4: 215-222.

Chou, F; R.C. Wiley and D.V. Schlimme (1991). Reverse osmosis and flavour retention in apple juice concentration. J. Food Sci. 56: 484-487.

Cliff. M.A.; L.R. Fukumoto; M.C. King; B.J. Edwards and B. Girard (2000). Sensory and physico-chemical properties of membrane filtered apple juices. Journal of Food Quality, 23: 171184.

Dixon, J. and W. Hewett (2001). Temperature of hypoxic treatment alters volatile compostion of juice from Fuji and Royal Gala apples. Postharvest Biology and Technology 22: 71-83.

Drake, S.R. and J.W. Nelson (1987). Apple juice quality as influenced by ultrafiltration. J. Food Qual. 9: 399-406.

Fadel, H.M.; M.A. Abd El-Mageed; M.M. Mostafa and N.F. El-Sharouny (2000). Quality and flavour stability of freeze dried banana and apple fruits. Egyptian J. of Nutrition, 15(1): 1-25.

Fallik, E.; D.D. Archbold.; T.R.H. Kemp,; J.H. Loughrin, and R.W. Collins, (1997). Heat treatment temporarily inhibits aroma volatile compound emission from Golden Delicious apples. $\boldsymbol{J}$. Agric. Food Chem. 45: 4038-4041.

Gilbert, J.M.; H. Young; R.D. Ball and S.H. Murray (1996). Volatile flavour compounds affecting consumer acceptability of kiwifruit. J. Sens. Stud. 11(3): 247-259.

Jordan, M.J.; C.A. Margaria; P.E. Shaw and K.L. Goodner (2002). Aroma active components in aqueous kiwifruit 
essence and kiwifruit puree by GC-MS and multidimensional GC/GC-O. $J$. Agric. Food Chem. 50: 5386-5390.

Jung, M.K. and S.K. Young, (1997). Comparative studies on the aroma and taste components of Korean and imported kiwifruits. Korean J. Food Sci. Technol. 29(4): 626-629.

Kakiuchi, N.; S. Moriguchi and H. Fukuda (1986). Composition of volatile compounds of apple fruits in relation to cultivars. J. Jpn. Soc. Hortic. Sci. 55: 280-289.

Larmond, E. (1967). Methods for Sensory Evaluation of Food-Publ. No. 1284, pp. 12-13, Canada Dept. of Agriculture, Ottawa.

Lavilla, T.; J. Puy; M.L. Lopez; I. Recasens and M. Vendrell (1999). Relationships between volatile production, fruit quality and sensory evaluation in Granny Smith apples stored in different controlled atmosphere treatments by means of multivariate analysis. J. Agric. Food Chem. 47: 3791-3803.

Lue, S.J. and B.H. Chiang (1989). Deacidification of passion fruit juice by ultrafiltration and ion-exchange processes. Int. J. Food Sci. Technol. 24: 395-401.

Lund, D.B. (1977). Design of thermal processes for maximising nutrient retention. Food Technology, 2: 71- 76.

Matheis, G. (1995). Plant Enzymes Linked to Flavour, Dragoco Report, Flavouring Information Service. Dragoco Gerberding and Co GMBH.

Matich, A.J.; H. Young; J.M. Allen; M.Y. Wang; S. Fielder; M.A. McNeilage and E.A. MacRae (2003). Actinidia arguta: voltile compounds in fruit and flowers. Phytochemistry 63: 285-301.

Moshonas, M.G. and P.E. Shaw (1997). Flavour and chemical comparison of pas- teurized and fresh Valencia orange juicesJ. of Food Quality 20: 31-40.

Myrna, O.; X. Nisperos-Carriedo and E.S. Philip (1990). Comparison of volatile flavour components in fresh and processed orange juice. J. Agric. Food Chem. 38: 10481052.

Paterson, V.J.; E.A. MacRae and H. Young (1991). Relationships between sensory properties and chemical composition of kiwifruit (Actinidia deliciosa). $\boldsymbol{J}$. Sci. Food Agric., 57(2): 235-251.

Peredi, K.; L. Vamos-Vigyazo and N. Kiss-Kutz (1981). Flavour losses in apple juice manufacture Nahrung Food. 25: 573-582

Pfannhauser, W. (1988). Sensorische und instrumentelle analytische untersuchungen des kiwi-aromas. Z. Lebensm. Unters Forsch 187: 224-228

Pino, J.A. (1997). Volatile constituents of tropical fruits. IV. Kiwifruit, star fruit and mangosteen. Alimentaria, 286: 4750.

Poll, L.; A. Rindom; T.B.T. Andersen and P. Hansen (1996). Availability of assimilates and formation of aroma compounds in apples as affected by the fruit/ leaf ratio. Physiologia. Plantarum 97: 223-227.

Rao, M.A.; T.E. Acree; H.J. Cooley and R.W. Ennis (1987). Clarification of apple juice by hollow fiber ultrafiltration: fluxes and retention of odour-active volatiles. J. Food Sci., 52: 375-377.

Rychlik, M.; P. Schieberle and W. Grosch (1998). Compilation of odour thresholds, Odour Qualities and Retention Indices of Key Food Odorants. Deutche Forschungsanstalt fur Lebensmittelchemie and Institut fur lebensmittelchemie der Technischen Universitat Munchen Garching. 
Schreier, P. (1981). Changes of odour compounds during the processing of fruit juices. Proceedings of Long Ashton Symposium, 7: 355371.

Sheu, M.J. and R.C. Wiley (1983). Preconcentration of apple juice by reverse osmosis. J. Food Sci. 48: 422-429.

Shimoda, M.; T. Katoh; J. Suzuki; A. Kawaraya; N. Igura, and I. Hayakawa (2003). Changes in the odours of reconstituted apple juice during thermal processing. Food Research International. 36: 439-445.

Steel, R.G.D. and J.H. Torrie (1980). Multiple Comparison in Principles and Procedures of Statistics”, $2^{\text {nd }}$ Ed p. 72., McGraw-Hill Book Co., New York.

Su, S.K. and R.C. Wiley (1998). Changes in apple juice flavour compounds during processing. J. Food Sci. 63: 688- 691.

Takeoka, G.R.; M. Guntert; R.A. Flath; R.E. Wurtz; W. Jennings (1986). Volatile constituents of kiwifruit (Actinidia chinensis Planch). J. Sci. Food Agric. 34: 576-578.

Takeoka, G.R. (1987). Studies of the Volatile Constituents of Kiwifruit (Aclinidia chinensis Planch) and Nectarine (Prunus persica nectarina), University of California: Davis, CA, p. 247.

Wan, X.M.; R.J. Stevenson; X.D. Chen and L.D. Melton (1999). Application of headspace solid-phase microextraction to volatile flavour profile development during storage and ripening of kiwifruit. Food Res. Int. 32(3): 175-183.
Winterhalter, P. (1991). Fruit IV. In Volatile Compounds in Foods and Beverages; Maarse, H., Ed.; TNO-CIVO Food Analysis Institute: Zeist, The Netherlands, pp. 389-410.

Young, H. and V.J. Paterson (1985). The effects of harvest maturity ripeness and storage on kiwifruit aroma. J. Sci. Food Agric., 36: 352-358.

Young, H. and V.J. Paterson (1990) The flavour of exotic fruit. In: Morton, I. D., Macleod, AJ. (Eds), Food Flavours. Part C. The Flavour of Fruit. Elsevier, New York, pp. 281-326.

Young, H. and V.J. Paterson (1995). Characterization of bound flavour components in kiwifruit. J. Sci. Food Agric. 68 (2): 257- 260.

Young, H.; V.J. Paterson and D.J.W. Burn (1983). Volatile aroma constituents of kiwifruit. J. Sci. Food Agric. 34: 8185.

Young, H.; J.M. Gilbert; S.H. Murry and R.D. Ball (1996). Causal effects of aroma compounds on Royal Gala apple flavour. J. Sci. Food Agric. 71: 329336.

Yu, Z.R. and B.H. Chiang (1986). Passion fruit juice concentration by ultrafiltration and evaporation. J. Food Sci. 51: 1501-1505.

Yulianti, F.; C.A. Reitmeier and T.D. Boylston (2004). Consumer sensory evaluation and flavour analysis of pasteurized and irradiated apple cider with potassium sorbate. J. Food Sci. 69(5): S193-S197. 
بحلة اتحاد الجحامعات العربية للدراسات والبحوث الزراعية ، جامعة عين شمس ، القاهرة ،14(2) ، 643-660 ، 2006

دراسة تأثير البستره والتخزين علي تلغيرات الطعم والثرائحة لمخلوط عصيري التفاح والكيوي

[41]

\author{
ماجدة عبد المنعم عبد المجيد 1 - عماد الدين راغب شعيشع 2 \\ 1 - قسر كيمياء مكسبات الطعم والرائحة - المركز القومي للبحوث - الاقي - القاهرة \\ 2- قسر بحوث الحاصلات البستانية - معهد بحوث تكنولوجيا الأغذية بالجيزة - مصر
}

هيدروكربونيه و 2 مركب كيتـوني وواحد الطب

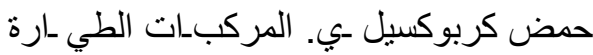

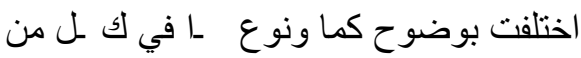
عصير التفـاح الط ـازج وعصبر الكيوي الطلاز ج و المخل ـوط المبست لـر و و العصبائر المخزنة خلال فترات التخزين.

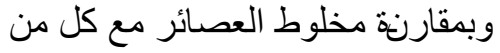

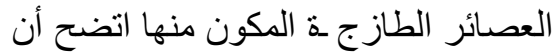

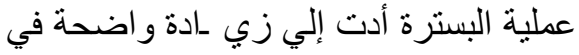

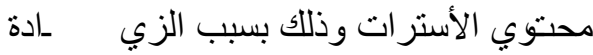

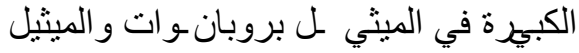

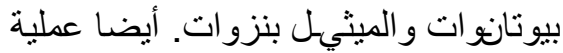

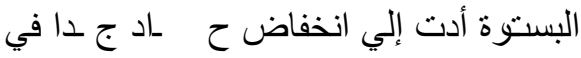
البيوتانول وه ـو المركب السائد كميا في إلي الفياض

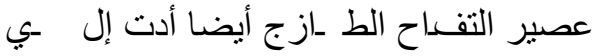

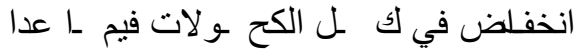
الايثانول مع اختف ـاء كح ول ول 3 كميثنيل بيو تانول و الهكسانـول. كذلك أدئ أدت البستره إلبي انخفـاض حاد في مركب 2 وكسينال

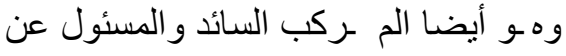
رائحة عصير الكيو ى الطازج مع زيادة
تهدف ه ذذه الدر اسة إلي معرفة تأثير

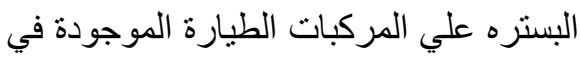
مخلزوط من عصيري التفاح و الكيوي أثناء

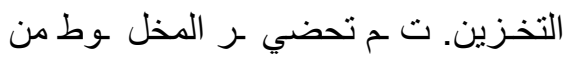
عصيري التفاح و الكي وي بنسبة حجما وتم بسترته وتخزينه لمدة ثلاثة وستة

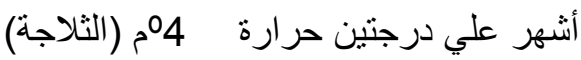
و25م (درجة حر ارة الغرفة) لحين تحليله. التقييم الحسي اوضح أن هناك النت اختلافات

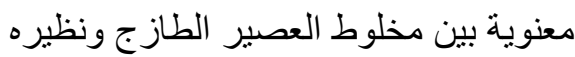
المبستّ م من حيث اللون و الطعم و الر ائحة

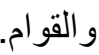
تم تجمي-ع المركبات الطياره لكل من الطن عصير التفــاح الط ـازج و وعصير الكيوي الطازج ومخلوط عصي ـر التفاح و الكيوي

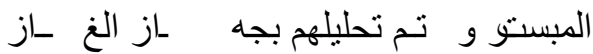
الكروماتوجافي - طيف الكتل مة (GC-MS) ولقد تم تعريف 33 مركب منها 18 مركب الكب

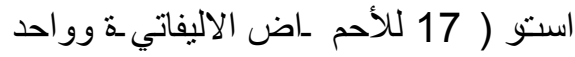

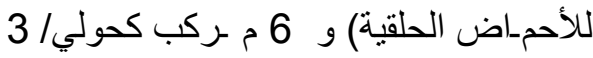

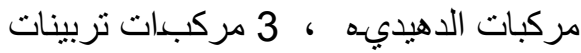


الليمونين وبدر اسـة تأثي ـر التخزين علي ستة أشهر سببها الزيادة الهائلة في تركيز

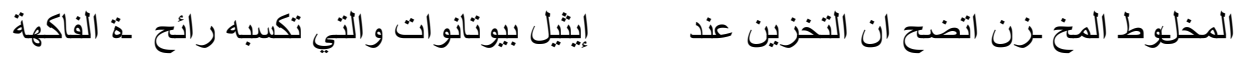

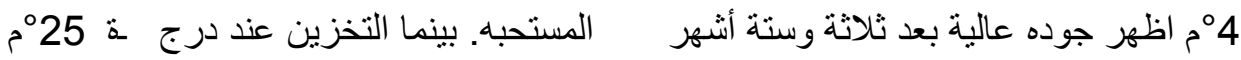

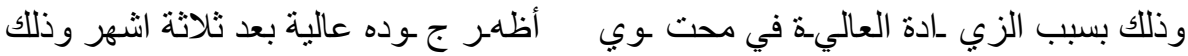
الاستو ات أيضا زيادة البيوتانول وزيادة 2 أبضا بسبب الزيادة الفائقة في تركيز الايثيل

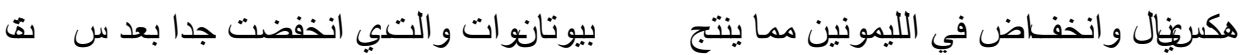

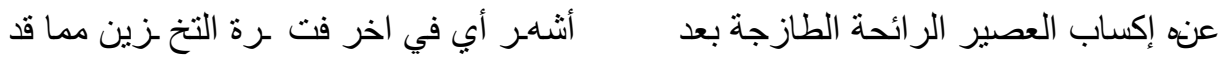

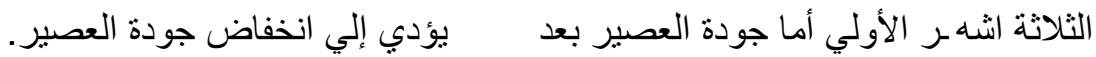

تحكيم: أ.د أحمد يوسف جبريل

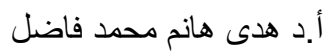

